\title{
Neuroethics: the institutionalization of ethics in neuroscience
}

Amer Cavalheiro Hamdan

\begin{abstract}
Recent advances in neuroscience have led to numerous ethical questions. Neuroethics is the study of ethical, legal and social advancements in neuroscience which, despite being a recently developed discipline, has a long historical tradition. The concern with ethical issues in neuroscience is extremely old and dates back to the philosophical and scientific traditions that originally sought to understand the relationship between the brain and behavior. More recently, the field of neuroethics has emerged in the context of public and academic debate over the consequences of the advances arising from neuroscience. In the current context, technological innovations, which have arisen from the expansion of neuroscience research, have raised new ethical dilemmas. This article aims to analyze the historical course of ethics within the field of neuroscience, specifically the appearance and the recent institutionalization of neuroethics.

Keywords: Neuroscience. Ethical analysis. Bioethical issues. Biomedical technology.
\end{abstract}

\section{Resumo}

\section{Neuroética: a institucionalização da ética na neurociência}

Os recentes avanços na neurociência suscitam inúmeras questões éticas. Neuroética é o estudo dos avanços éticos, legais e sociais em neurociência. Apesar de ser uma disciplina desenvolvida recentemente, a neuroética tem uma longa tradição histórica. A preocupação com questões éticas na neurociência é antiga e remonta às tradições filosóficas e científicas que originalmente tinham procurado compreender a relação entre cérebro e comportamento. Mais recentemente, o campo da neuroética surgiu no contexto do debate público e acadêmico sobre os efeitos dos avanços decorrentes da neurociência. No contexto atual, as inovações tecnológicas, que surgiram do crescimento da pesquisa em neurociência, levantaram novos dilemas éticos. Este artigo tem como objetivo analisar o curso histórico da ética no campo da neurociência, especificamente a recente institucionalização da neuroética.

Palavras-chave: Neurociência. Análise ética. Questões bioéticas. Tecnologia biomédica.

\section{Resumen}

\section{Neuroética: la institucionalización de la ética en neurociencia}

Los avances recientes en neurociencia han dado lugar a numerosas cuestiones éticas. La Neuroética es el estudio de los avances éticos, legales y sociales en neurociencia. A pesar de ser una disciplina desarrollada recientemente, la neuroética tiene una larga tradición histórica. La preocupación por las cuestiones éticas en la neurociencia es antigua y se remonta a las tradiciones filosóficas y científicas que originalmente habían tratado de comprender la relación entre cerebro y comportamiento. Más recientemente, el campo de la neuroética surgió en el contexto del debate público y académico sobre las consecuencias de los avances derivados de la neurociencia. En el contexto actual, las innovaciones tecnológicas, que han surgido del crecimiento de la investigación en neurociencia, han planteado nuevos dilemas éticos. Este artículo pretende analizar el curso histórico de la ética en el campo de la neurociencia, específicamente la aparición y la reciente institucionalización de la neuroética.

Palabras clave: Neurociencia. Análisis ético. Cuestiones bioéticas. Tecnología biomédica.

Doutor amerc.hamdam@gmail.com - Universidade Federal do Paraná. Curitiba/PR, Brasil.

\section{Correspondência}

Universidade Federal do Paraná. Programa de Pós-Graduação em Psicologia. Praça Santos Andrade 50, Prédio Histórico, sala 216 CEP 80060-010. Curitiba/PR, Brasil.

Declara não haver conflito de interesse. 
This article aims to analyze the historical course taken by ethics within the fields of neuroscience, specifically the emergence and recent institutionalization of neuroethics. In recent years, research and public interest in neuroscience have grown significantly. Major investments in government-sponsored projects, such as the Brain Research through Advancing Innovative Neurotechnologies project of the US government ${ }^{1}$ and the Human Brain Project of the European Union ${ }^{2}$, represent significant examples of the growth of research in neuroscience.

These projects have produced new tools and techniques to observe and intervene in the structure and functioning of the brain. Neuroimaging devices ${ }^{3}$, neurosurgery techniques ${ }^{4}$, cranial stimulation devices ${ }^{5}$, psychopharmacologic drugs ${ }^{6}$, and numerous other neurotechnological products and techniques have resulted from the advancement of the current research in neuroscience. As a result, the way we understand and explain the relationship between brain and mind are changing. Such change directly impacts the diagnosis and treatment of neurological and psychiatric diseases.

Another important development over the last few years has been the increase in public interest about the application of neuroscientific knowledge ${ }^{7-9}$. In particular, there has been growing interest in the application of neuroscientific knowledge to nonmedical areas such as education ${ }^{10}$, marketing ${ }^{11}$ and justice ${ }^{12,13}$. These emerging applications have brought about lifestyle and societal changes. Educational methodologies and curriculum proposals have been founded upon the knowledge derived from neuroscience ${ }^{10,14}$. Research studies in neuromarketing have investigated consumer preferences using brain-imaging technologies such as $\mathrm{FMRI}$ in support of advertising and product marketing campaigns ${ }^{15}$. Major companies such as Google, Microsoft, Apple and Facebook have created new products based on consumer preferences based on studies of neuromarketing ${ }^{11,15,16}$.

Similarly, judicial decisions, such as the form and extent of punishment, have been influenced by the knowledge derived from neuroscience ${ }^{12,13}$. The determining of criminal liability or responsibility has been questioned based on studies arising from the current understanding of brain functioning. For example, knowledge of the functioning of certain regions of the frontal cortex, specifically those related to social behavior and aggression, have been used to justify the charging or acquittal of criminal responsibility of people with functional alterations in this area of the brain.

The use of psychopharmacological stimulants and instruments for the electrical stimulation of the brain increase cognitive potential. Yet certain claims have overstepped the bounds of research-based medical practice and unregulated market consumption has been freely permitted ${ }^{6}$. Moreover, brain stimulation devices for 'do-it-yourself'-style cognitive enhancement have raised concerns among experts concerning the risks and benefits of this practice ${ }^{17}$.

Public and academic debate over the ethical, social and cultural implications of research in neuroscience, has therefore increased, especially regarding issues related to privacy, security, justice and freedom ${ }^{16}$. It was in this historical context that neuroethics emerged.

\section{The neuroethics field of study}

Neuroethics is the study of the ethical, social and legal implications of advances in neuroscience ${ }^{18,19}$. It delves into the moral problems that motivate and guide human behavior, specifically addressing the problems that arise from the research, products and expert practice of neuroscience. Neuroethics addresses the theoretical, empirical, practical and political aspects of the intersection of neuroscience and ethics ${ }^{20}$. Whereas bioethics is concerned with more general aspects of human behavior in the context of the life and health sciences, neuroethics emphasizes more specific questions concerning the relationship between the brain and behavior. Of course, neuroethics shares several areas of commonality with bioethics.

Neuroethics presents two research traditions or approaches: the ethics of neuroscience and the neuroscience of ethics ${ }^{21}$. The first investigates practical issues such as planning, conducting, analyzing and disseminating the results of research in neuroscience. It includes research aspects related to health care, such as those involving health professionals, patients and families, as well as the use of new neurotechnologies. The second approach investigates issues pertaining to moral philosophy and its relationship to the brain. Themes such as freedom, self-control, personal identity and intentionality recurrently occur in the study of the neuroscience of ethics ${ }^{22}$. These two traditions of neuroethics are interrelated and mutually influence 
each other. Such approaches are discussed in light of recent advances in brain functioning.

In other words, neuroethics is a field of study that seeks to respond to the ethical, legal and social questions concerning the progress of research in neuroscience. It seeks to do so from a foundational, practical point of view. Neuroethics was born from both current questions regarding clinical bioethics (the ethics of neuroscience) and from issues related to moral philosophy (the neuroscience of ethics).

Neuroethics is relevant because recent advances in neuroscience demand answers to essentially ethical dilemmas. For example, should a health professional disclose a diagnosis of Alzheimer's disease to asymptomatic individuals or minimally symptomatic patients? At what point should standard medical or palliative treatment of patients with advanced neurological disease be stopped? How should the problem of the social stigma of individuals with neurological impairment be addressed? Is it morally acceptable to use cognitive enhancers to prepare for academic and job-related assessments? These and other questions require morally justifiable answers.

The study of neuroethics is particularly important for making increasingly better decisions regarding the diagnosis and treatment of neurological and psychiatric diseases, allowing patients and families to guide the course of their own treatment. It assists in the formulation of public policies in relation to health issues and education. To better understand the issues related to neuroethics, it is important to review some historical aspects of the relationship between neuroscience and ethics.

\section{Neuroscience and ethics}

Interest in understanding the relationship between the body and soul or between the brain and the mind is old. Archaeological remains of trepanned skulls, dating from approximately 2500 BC, reveal the frequent practice of neurosurgical procedures in different cultures, probably to address brain disorders ${ }^{23-25}$. The Edwin Smith Papyrus, dating from 1500 BC, is the oldest written historical record detailing the relationship between the brain and the clinical manifestations of various neurological diseases ${ }^{26,27}$.

However, it is the Hippocratic Oath (fifth century $\mathrm{BC}$ ) that reveals the oldest concern with ethical issues in medical practice ${ }^{28}$. The study of ethics was born within the philosophical traditions of ancient Greece in order to systematize the "good manners" of medical practice. Such traditions were intended to constitute universal principles that would not change, designed to regulate human behavior ${ }^{29}$. Even as late as the Renaissance age, however, conceptions of mental illness were associated with superstition ${ }^{30}$. Only in the Enlightenment, from the eighteenth century on, did scientific knowledge of the brain gain credence, 'credentialing' the new science through the development of new methodologies and tools for investigating the central nervous system.

However, it was not until the nineteenth century that the first neurophysiologists related cognitive functions (speech, comprehension of language, and social behavior) to certain areas of the brain. This started a debate between the localizationist school, which defended the position that every mental function has a specific location in the brain, and the holistic school, which stated that no specific location for cognitive functions exists ${ }^{31}$. At this point, the discussion of issues relating to the relationship between neuroscience and ethics was restricted to academic circles and clinical practice.

In the late nineteenth century, public debate marked a new phase in the relationship between neuroscience and society, with several events leading to the discussion of this relationship. Firstly, mental health began to be reformed in the search for a more humane treatment of mental patients ${ }^{32,33}$. Secondly, questions were raised regarding the use of lobotomies as treatments for mental diseases ${ }^{34,35}$. Thirdly, it was revealed that during World War II, prisoners in Nazi concentration camps had been subjected to cruel experiments ${ }^{36,37}$. Fourthly, research was disseminated regarding the intentional withholding of treatment for syphilis in a study conducted by the Public Health Service of the United States in Tuskegee, Alabama (USA) ${ }^{38,39}$. These events marked the beginning of a public debate on ethical issues in medical practice and research involving humans.

The direct consequence of these discussions was the creation of various codes, statements and reports to establish ethical principles to regulate research and clinical practice involving human beings, namely the Nuremberg Code (1948) ${ }^{40}$; the Declaration of Helsinki (1964) ${ }^{41}$ of the World Medical Association; the "Belmont Report" (1978) ${ }^{42}$ of Biomedical and Behavioral Research and the Universal Declaration on Bioethics and Human Rights (2005) ${ }^{43}$ of the United Nations Educational Scientific and Cultural Organization (UNESCO). 
The "Belmont Report", presented by the National Commission for the Protection of Human Subjects of Biomedical and Behavioral Research (created by congress), established three basic principles for human research: 1) respect for people, 2) beneficence and 3) justice. Subsequently, these principles were extended to four, and the principles of non-maleficence, beneficence, autonomy and justice ${ }^{44}$ are currently internationally accepted as the normative standards for addressing ethical issues related to research and healthcare.

The principle of non-maleficence states that the health professional should avoid harm and refrain from doing any harm to others. No diagnoses and treatments should cause harm to the physical, mental or social aspects of treatment. In many situations, however, it is not easy to observe this principle. Some patients with Alzheimer's disease, for example, present behavioral symptoms such as delusions, hallucinations, and aggressiveness. These behaviors often cause conflicts within family relationships or with the caregiver. However, the use of anti-psychotic drugs can exacerbate cognitive impairment. What is the best decision to make? Should such medication be administered? In situations such as this, the principle of beneficence might be considered when choosing the best option.

The principle of beneficence states that there is a duty to assist and promote the wellbeing of others. All health professionals should seek the best benefit to the patient and act not only to prevent damage (per the principle of non-maleficence) but also to bring maximum benefit to the patient. For example, the principle includes the duty to protect and defend the rights of family members, caregivers and patients with Alzheimer's disease.

The third principle is that of autonomy. It is the duty of the health professional to respect a person's self-determination or his or her decision-making power over himself or herself. The individual should have the right to make decisions regarding personal choices. This principle is related to freedom. A patient with the ability to make her or his own decisions, for example, should have freedom of choice as to whether to pursue specific treatment modalities. In the case of Alzheimer's disease, it is precisely this capability that is compromised, with the guardian or caregiver becoming responsible for the autonomy of the patient.

Conflicts with the principle of autonomy are defined as the paternalistic actions that often occur within the health services. This conflict occurs when the health care provider denies the patient or family the freedom to express their own interests, desires, and wishes in relation to health services. It stems from the view that only the provider knows what is best and that only the provider is able to make the best decisions on their behalf. Of course, the health professional has knowledge and is accredited to make decisions regarding the diagnosis and treatment of the patient. However, such understanding of the problem and how to treat it should not be imposed without consent.

The fourth principle is that of justice. Justice is the duty of ensuring the equitable distribution of duties and social benefits. The health professional should promote equity in relation to the conditions of evaluation and treatment for all.

These principles are considered prima facie duties, which must be met, but which are not necessarily ranked hierarchically. In a given situation, when there are conflicts between them, it should be established how, when and why one principle ought to have predominance over the other.

Another important milestone was the Universal Declaration on Bioethics and Human Rights by the Unesco General Conference (2005), which defined a normative ethical framework to support the implementation of laws in different countries. However, it was the late twentieth century, in the midst of discussions regarding the social and ethical implications of advances in neuroscience, in which specific interest in neuroethics rose. The first report on the ethical implications of advances in neuroscience was published in 1995 by the International Bioethics Committee (IBC) created by UNESCO ${ }^{20}$.

The 1990s, the so-called Decade of the Brain (1990-1999), brought great advances and challenges to understanding the brain ${ }^{45,46}$. Yet contradictorily, despite these advances, so-called neuromyths remain in society. Neuromyths are false beliefs about the functioning of the brain, such as the claim that humans typically use only approximately $10 \%$ of their mental capacity ${ }^{47,48}$. Gaps therefore remain between the advances made by neuroscientific research, the understanding of this knowledge, and the general public's use and appropriation of the same.

\section{The emergence of neuroethics}

Neuroethics emerged from the research interests of neuroscientists, psychologists, 
physicians and philosophers ${ }^{49-51}$. Certain events marked its emergence in the public sphere, such as the "Neuroethics: mapping the field" conference in San Francisco (USA) in $2002^{52}$. This conference was sponsored by the Dana Foundation, the University of California and Stanford University. It brought together over 150 professionals from different specialties, among them bioethicists, psychologists, philosophers, doctors and lawyers. At the opening conference, William Safire, president of the Dana Foundation, defined neuroethics as the assessment of what is right or wrong, good or bad, about the treatment, or improvement, or intrusion or manipulation of the human brain ${ }^{52}$. In parallel with this conference, the first articles in scientific journals discussing the importance of ethical issues in relation to technological advances neuroscience were published ${ }^{19,21,53}$.

However, the word neuroethics first appeared in 1973, in the article entitled "Neuro-ethics of walking in the newborn," written by Anneliese Pontius and published in the journal Perceptual and motor skills. This article analyzed ethical issues related to research on newborns ${ }^{54}$.

The institutionalization of neuroethics has occurred as an outgrowth of the production and dissemination of domain-specific knowledge and the process of organizing this knowledge through the work of scientific associations, journals, research programs and university research centers. An important milestone for the development of neuroethics as a field of study was the creation in 2006 of the International Neuroethics Society (INS), formerly the Neuroethics Society. The mission of the INS is to promote the development and responsible application of international, interdisciplinary neuroscience through research, education, outreach, and public engagement for the benefit of people from all nations, ethnicities, and cultures.

The Society for Neuroscience (SfN) and the International Brain Research Organization (IBRO) have also promoted congresses and conferences for the development of research in neuroethics. In addition to these international organizations, other scientific and professional associations have promoted the debate on ethical issues in neuroscience. Participating professionals include neurologists, psychiatrists, psychologists, social workers, among others.

The institutionalization of neuroethics is also evidenced by the creation of scientific journals specific to the domain, as well as the placement of neuroethics articles in numerous professional journals such as: Neuroethics, the American Journal of Neuroscience Bioethics, the American Journal of Law and Medicine, Bioethics, the Cambridge Quarterly of Healthcare Ethics, the Journal of Clinical Ethics, the Journal of Medicine and Philosophy, Philosophy, Ethics and Humanities in Medicine, and the Journal of Bioethical Inquiry. Nor are scientific publications related to neuroethics limited to articles published in specialized journals.

This process is also evident in the creation of programs and research centers in various parts of the world, including the following: the Center for Neuroscience and Society of University of Pennsylvania, Philadelphia, USA, the Montreal Neuroethics Network of McGill University, Montreal, Canada, the National Core for Neuroethics of the University of British Columbia, Vancouver, Canada, the Neuroethics Research Unit of the Institut de Recherche Clinique de Montreal, Montreal, Canada, the Neuroethics Studies Program of the Pellegrino Center for Clinical Bioethics of the Georgetown University Medical Center, Washington DC, USA, the Oxford-Wellcome Centre for Neuroethics of the University of Oxford, in the UK, the Neuroethics Research Group of the World Federation of Neurology, and the Munich Center for Neurosciences of the Ludwig-Maximilians University of Munich, in Germany.

\section{Final considerations}

Although neuroethics has only recently been established as an academic discipline, it has an extremely long history, dating back to the interest in antiquity in knowledge of the brain and ethical issues related to treatment. Neuroethics developed from within the philosophical and scientific traditions, which were aimed at understanding the human motivations of ethical behavior. In recent years, new neuroscientific methodologies and tools, such as neuroprostheses, and psychiatric drugs have brought about lifestyle and societal changes. New neurotechnologies present ethical dilemmas that require thorough discussion. The institutionalization of neuroethics, through the creation of scientific associations, academic journals, university programs and research centers, has provoked an intense and fruitful debate over the ideal relationship between neuroscience and ethics. 


\section{Referências}

1. Jorgenson LA, Newsome WT, Anderson DJ, Bargmann Cl, Brown EN, Deisseroth $\mathrm{K}$ et al. The BRAIN Initiative: developing technology to catalyse neuroscience discovery. Philos Trans R Soc Lond B Biol Sci. 2015;370(1668).

2. Rose N. The human brain project: social and ethical challenges. Neuron. 2014;82(6):1212-5.

3. di Porzio U. The brain from within. Front Hum Neurosci. 2016;10:265.

4. Giordano J. A preparatory neuroethical approach to assessing developments in neurotechnology. Virtual Mentor. 2015;17(1):56-61.

5. Bell E, Racine E, Chiasson P, Dufourcq-Brana M, Dunn LB, Fins JJ et al. Beyond consent in research: revisiting vulnerability in deep brain stimulation for psychiatric disorders. Camb Q Healthc Ethics. 2014;23(3):361-8.

6. Sahakian BJ, Bruhl AB, Cook J, Killikelly C, Savulich G, Piercy T et al. The impact of neuroscience on society: cognitive enhancement in neuropsychiatric disorders and in healthy people. Philos Trans R Soc Lond B Biol Sci. 2015;370(1677):20140214.

7. O'Connor C, Rees G, Joffe H. Neuroscience in the public sphere. Neuron. 2012;74(2):220-6.

8. Racine E, Waldman S, Rosenberg J, Illes J. Contemporary neuroscience in the media. Soc Sci Med. 2010;71(4):725-33.

9. van Atteveldt NM, van Aalderen-Smeets SI, Jacobi C, Ruigrok N. Media reporting of neuroscience depends on timing, topic and newspaper type. Plos One. 2014;9(8):e104780.

10. Sigman M, Pena M, Goldin AP, Ribeiro S. Neuroscience and education: prime time to build the bridge. Nat Neurosci. 2014;17(4):497-502.

11. Ulman YI, Cakar T, Yildiz G. Ethical issues in neuromarketing: "I consume, therefore I am!". Sci Eng Ethics. 2015;21:1271-84.

12. Jones OD, Marois R, Farah MJ, Greely HT. Law and neuroscience. J Neurosci. 2013;33(45):17624-30.

13. Meynen G. Neurolaw: recognizing opportunities and challenges for psychiatry. J Psychiatry Neurosci. 2016;41(1):3-5.

14. Horvath JC, Donoghue GM. A bridge too far - revisited: reframing bruer's neuroeducation argument for modern science of learning practitioners. Front Psychol. 2016;7:377.

15. Breiter HC, Block M, Blood AJ, Calder B, Chamberlain L, Lee $\mathrm{N}$ et al. Redefining neuromarketing as an integrated science of influence. Front Hum Neurosci. 2015;8:1073.

16. Illes J, Sahakian BJ. Oxford handbook of neuroethics. Oxford: Oxford University Press; 2013.

17. Wurzman R, Hamilton RH, Pascual-Leone A, Fox MD. An open letter concerning do-it-yourself users of transcranial direct current stimulation. Ann Neurol. 2016;80(1):1-4.

18. Farah MJ. Neuroethics: the ethical, legal, and societal impact of neuroscience. Annu Rev Psychol. 2012;63:571-91.

19. Moreno JD. Neuroethics: an agenda for neuroscience and society. Nat Rev Neurosci. 2003;4(2):14953.

20. Vicent JD. Ethics and neuroscience. [Internet]. Paris: Unesco; 1995 [acesso 18 maio 2017]. Disponível: http://bit.ly/2sfnTWE

21. Roskies A. Neuroethics for the new millenium. Neuron. 2002;35(1):21-3.

22. Darragh M, Buniak L, Giordano J. A four-part working bibliography of neuroethics: part 2: Neuroscientific studies of morality and ethics. Philos Ethics Humanit Med. 2015;10:2.

23. Gonzalez-Darder JM. Cranial trepanation in primitive cultures. Neurocirugia (Astur). 2016;28(1):28-40.

24. Petrone P, Niola M, Di Lorenzo P, Paternoster M, Graziano V, Quaremba G et al. Early medical skull surgery for treatment of post-traumatic osteomyelitis 5,000 years ago. Plos One. 2015;10(5):e0124790.

25. Andrushko VA, Verano JW. Prehistoric trepanation in the Cuzco region of Peru: a view into an ancient Andean practice. Am J Phys Anthropol. 2008;137(1):4-13.

26. Kamp MA, Tahsim-Oglou Y, Steiger HJ, Hanggi D. Traumatic brain injuries in the ancient Egypt: insights from the Edwin Smith Papyrus. J Neurol Surg A Cent Eur Neurosurg. 2012;73(4):230-7.

27. Minagar A, Ragheb J, Kelley RE. The Edwin Smith surgical papyrus: description and analysis of the earliest case of aphasia. J Med Biogr. 2003;11(2):114-7.

28. Antoniou SA, Antoniou GA, Granderath FA, Mavroforou A, Giannoukas AD, Antoniou AI. Reflections of the Hippocratic Oath in modern medicine. World J Surg. 2010;34(12):3075-9.

29. Maclntyre A. A short history of ethics: a history of moral philosophy from the Homeric age to the 20th century. Abingdon: Routledge; 2003.

30. Diamantis A, Sidiropoulou K, Magiorkinis E. Epilepsy during the Middle Ages, the Renaissance and the Enlightenment. J Neurol. 2010;257(5):691-8.

31. Hamdam AC, Pereira APA, Riechi TIJS. Avaliação e reabilitação neuropsicológica: desenvolvimento histórico e perspectivas atuais. Interação psicol. 2011;15:47-58.

32. Engstrom EJ. History of psychiatry and its institutions. Curr Opin Psychiatry. 2012;25(6):486-91.

33. Ebert A, Bar KJ. Emil Kraepelin: a pioneer of scientific understanding of psychiatry and psychopharmacology. Indian J Psychiatry. 2010;52(2):191-2.

34. Faria MA Jr. Violence, mental illness, and the brain: a brief history of psychosurgery: part 1: From trephination to lobotomy. Surg Neurol Int. 2013;4:49. 
35. Masiero AL. Lobotomy and leucotomy in Brazilian mental hospitals. Hist Ciênc Saúde-Manguinhos. 2003;10(2):549-72.

36. Weisz GM. Nazi medical experiments on Australian prisoners of war: commentary on the testimony of an Australian soldier. J Law Med. 2015;23(2):457-9.

37. Oehler-Klein S, Preuss D, Roelcke V. The use of executed Nazi victims in anatomy: findings from the Institute of Anatomy at Giessen University, pre and post 1945. Ann Anat. 2012;194(3):293-7.

38. Gamble VN. Under the shadow of Tuskegee: African Americans and health care. Am J Public Health. 1997;87(11):1773-8.

39. Brandon DT, Isaac LA, LaVeist TA. The legacy of Tuskegee and trust in medical care: is Tuskegee responsible for race differences in mistrust of medical care? J Natl Med Assoc. 2005;97(7):951-6.

40. Nuremberg Military Tribunals. Trials of war criminals before the Nuremberg military tribunals under control council law no 10. Nuremberg; 1949. v. 10, p. 181-2.

41. Human Experimentation: Code of ethics of the World Medical Association (Declaration of Helsinki). Can Med Assoc J. 1964;91(11):619.

42. The National Commission for the Protection of Human Subjects of Biomedical and Behavioral Research. The Belmont Report: Ethical principles and guidelines for the protection of human subjects of research: The National Commission for the Protection of Human Subjects of Biomedical and Behavioral Research. Washington: Government Printing Office; 1978.

43. United Nations Educational, Scientific and Cultural Organizations. Universal declaration on bioethics and human rights. Paris: Unesco; 2005.

44. Beauchamp TL, Childress JF. Principles of biomedical ethics. New York: Oxford University Press; 2001.

45. Baddeley A, Bueno O, Cahill L, Fuster JM, Izquierdo I, McGaugh JL et al. The brain decade in debate: I. Neurobiology of learning and memory. Braz J Med Biol Res. 2000;33(9):993-1002.

46. Morris K. Advances in "brain decade" bring new challenges. Lancet. 2000;355(9197):45.

47. Dekker S, Lee NC, Howard-Jones P, Jolles J. Neuromyths in Education: Prevalence and predictors of misconceptions among teachers. Front Psychol. 2012;3:429.

48. Howard-Jones PA. Neuroscience and education: myths and messages. Nat Rev Neurosci. 2014;15(12):817-24.

49. Buniak L, Darragh M, Giordano J. A four-part working bibliography of neuroethics: part 1: overview and reviews--defining and describing the field and its practices. Philos Ethics Humanit Med. 2014;9:9.

50. Figueroa G. Neuroethics: the pursuit of transforming medical ethics in scientific ethics. Biol Res. 2016;49:11.

51. Leefmann J, Levallois C, Hildt E. Neuroethics 1995-2012: A bibliometric analysis of the guiding themes of an emerging research field. Front Hum Neurosci. 2016;10:336.

52. Marcus SJ. Neuroethics: mapping the field. Conference proceedings. New York: Dana Press; 2002. p. 5.

53. Farah MJ. Emerging ethical issues in neuroscience. Nat Neurosci. 2002:5(11);1123-9.

54. Pontius AA. Neuro-ethics of "walking" in the newborn. Percept Mot Skills. 1973;37(1):235-45.

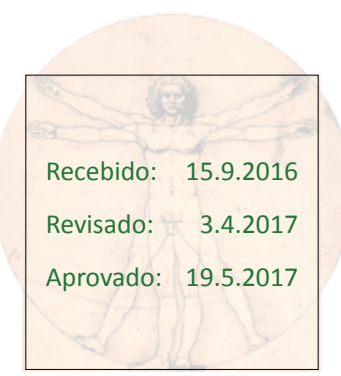

